\title{
ANALYSIS OF HEAT SHOCK PROTEIN IN CULTURE MEDIA OF STAPHYLOCOCCUS AUREUS
}

\author{
INAS M.GAMAL ${ }^{*}$ and A.M. NABIH ${ }^{* *}$ \\ "Immunology Unit, Animal Reproduction Research Institute (ARRI), Gizza, Egypt. \\ ${ }^{* *}$ Mastitis and neonatal diseases department, Animal Reproduction Research Institute (ARRI), Gizza, Egypt.
}

\begin{tabular}{|c|c|}
\hline & ABSTRACT \\
\hline $\begin{array}{l}\text { Received at: } 6 / 3 / 2013 \\
\text { Accepted: } 10 / 4 / 2013\end{array}$ & $\begin{array}{l}\text { In this study Staphylococcus aureus strain isolated from bovine mastitic milk was } \\
\text { subjected to different heat treatments }\left(25,37 \text { and } 50^{\circ} \mathrm{C}\right) \text { for } 24 \text { and } 48 \text { hrs. Each } \\
\text { time the heat treated strain was incubated with bovine lymphocytes in vitro. One } \\
\text { dimentional SDS-PAGE and dendrogram analysis were applied on the extracted } \\
\text { heat shock proteins (HSPs) that were expressed from Staphylococcus aureus strain } \\
\text { when it was incubated at the same temperatures for the same incubation times. } \\
\text { Transformation assay using MTT reduction showed highly significant stimulation } \\
\text { in response to phytoheamagglutinin when incubated with } 50^{\circ} \mathrm{C} \text { heat treated } \\
\text { Staphylococcus aureus for } 24 \text { and } 48 \text { hrs. The SDS-PAGE revealed that HSPs } 70 \\
\text { were highly expressed by } 22.7 \% \text { when the Staphylococcus aureus strain was } \\
\text { exposed to } 50^{\circ} \mathrm{C} \text { for } 48 \text { hrs, while the lowest percentage } 5.3 \% \text { was found when it } \\
\text { was exposed to } 25^{\circ} \mathrm{C} \text { for } 48 \text { hrs. The dendrogram analysis of the HSPs showed } \\
\text { that the highest similarity ( } 84.21 \% \text { ) was found between HSPs expressed after } \\
\text { exposure of } \text { Staphylococcus aureus strain to50 } \mathrm{C} \text { for } 24 \text { hrs (Lane } 1 \text { ) and those } \\
\text { exposed to } 50^{\circ} \mathrm{C} \text { for } 48 \text { hrs. (Lane } 2 \text { ). We concluded that, heat shock proteins have } \\
\text { a stimulatory effect on the most important immune cells (lymphocytes) and the } \\
\text { electrophoretic profile showed that the increasing time and degree of heat stress } \\
\text { produced more prominent level of these heat stress proteins. }\end{array}$ \\
\hline
\end{tabular}

Key words: Electrophoresis, heat shock proteins, immune response, lymphocytes transformation.

\section{INTRODUCTION}

Staphylococcus aureus is one of the most common causes of bovine mastitis in modern dairies worldwide and the most common mastitis pathogen isolated from raw milk. It is easily transmissible and infections caused by $S$. aureus respond poorly to treatment. The economic losses due to $S$. aureus mastitis are considerable, and include decrease in milk production, reduced milk quality through contamination by bacteria and increased milk SCC, veterinary and treatment costs, premature culling of cows and loss of genetic potential. Mastitis caused by $S$. aureus also adversely affects welfare of dairy cows.

Another facet of $S$. aureus pathogenesis is the organism's ability to maintain cellular homeostasis while enduring environmental challenges, such as changes in host cell temperature or exposure to phagocyte-mediated reactive temperature species Voyich et al. (2005).

Heat shock proteins (HSP) are a class of functionally related proteins involved in the folding and unfolding of other proteins. Their expression is increased when cells are exposed to elevated temperatures or other stress as infection, inflammation, exercise, exposure of the cell to toxins (ethanol, arsenic, trace metals, and ultraviolet light,. De Maio (1999). HSPs are found in virtually all living organisms, from bacteria to humans. They are named according to their molecular weight. Forexample, Hsp60, Hsp70 and Hsp90 (the most widely-studied HSPs) refer to families of heat shock proteins on the order of 60, 70, and 90 kilodaltons in size, respectively. Srivastava (2004).

The focus of the current work is to define the $S$. aureus growth temperature as a stress response factor and it's mechanisms of producing heat shock protein. This may provide better understanding of the organism's ability to adapt to an environmental challenges and further elucidiate the strategies of cellular immune response for the bacterial infection.

\section{MATERIALS and METHODS}

\section{Bacterial strains:}

Our pure research strains have been obtained from milk samples of mastitic cows from different governorates in Egypt. Samples were cultured on mannitol salt agar (specific media), blood agar (for detection of haemolysis) and nutrient agar (Oxoid media). Isolates were identified biochemically by catalase, oxidase, urease tests, phosphatase test (Quinn et al., 2002), coagulase test (Koneman et al., 
1988), sugar fermentation, nitrate reduction test, (Cruickshank et al., 1975) and Ornithine decarboxylase test (Kloos et al., 1991). Final identification was done using API-Staph.kit (bioMerieux) according to manufactures instructions.

\section{Stress Induction:}

Field strain of S. aureus was grown in $250 \mathrm{ml}$ of brain heart infusion broth. Heat shock stress conditions were imposed according to the following procedures:

- The culture broth was incubated at 25,37 and $50{ }^{\circ} \mathrm{C}$ respectively.

- At each temperature, samples were taken at intervals after heat shock, and crude cell extracts were prepared. Culture samples were taken after $24 \mathrm{~h}$ and $48 \mathrm{~h}$. The density of bacterial cells was measured spectophotometrically $(540 \mathrm{~nm})$ and the cells number was calculated by using previously determined standard curves (based on CFU counts) C L S I (2005). Bacterial culture concentration was adjusted to $5 \times 10^{6}$ bacterial cells for each treatment using 0.5 McFarland tube.

\section{Lymphocytes transformation:}

Blood samples: blood samples were taken during the experiment on heparin for separation of $\mathrm{T}$ lymphocyte by aseptically collection, centrifugation at $2500 \mathrm{rpm}$ at $4 \mathrm{c}^{\circ}$ for 30 minutes, the leukocytic layer transferred on to sterilized tissue culture tube, overlayed on ficol (1.077) in sterilized tissue culture tube, centrifuged at $4000 \mathrm{rpm}$ for 30 minutes at room temperature. The mononuclear interphase layer was taken for separation of T-lymphocyte for lymphocyte transformation assay using MTT reduction assay according to Chin et al. (2000). Briefly the cells washed twice by (Hank's Balanced Salt Solution (HBSS), the cells suspended in RPMI in number $5 \times 10^{6} / \mathrm{ml}$ and cultivated in sterilized 96 well tissue culture plate with phytohaemagglutinin $(15 \mathrm{ug} / \mathrm{ml})$ and $10 \%$ fetal calf serum and incubated for 72 hour in $10 \% \mathrm{CO}_{2}$ incubator at $37{ }^{\circ} \mathrm{C}$, then we add MTT $5 \mathrm{mg} / \mathrm{ml}$ PBS for 4 hour then lyses by lysis buffer, the lysate then measured spectrophotometrically at $570 \mathrm{~nm}$.

S. aureus culture supernatant proteins by SDSPAGE electrophoresis:

Samples were taken at intervals after heat shock, and cellfree supernatant proteins were prepared using the protocol of Love and Hirsh (1994). Bacterial cells were removed from cultures by centrifugation at $7,000 \mathrm{xg}$ for $20 \mathrm{~min}$ and subsequent filtration through a $0.22-\mathrm{mm}$-pore-size filter. Proteins from the cellfree culture supernatants were then precipitated by adding $10 \%(\mathrm{v} / \mathrm{v})$ trichloroacetic acid and recovered by centrifugation at 70,000 rpm for $20 \mathrm{~min}$. Pellets were resuspended in $4 \mathrm{ml}$ of phosphate-buffered saline
(PBS), and proteins were precipitated again by adding $20 \mathrm{ml}$ of cold acetone. After centrifugation at 70,000 rpm for $20 \mathrm{~min}$, the pellets were washed once with cold acetone, dried, and resuspended in $250 \mathrm{ml}$ of PBS. Polyacrylamide gel electrophoresis, Coomassie blue staining analysis of proteins was carried out by standard protocols (Maniatis et al., 1982).

\section{Computer-aided Analysis of the Gels:}

Images of the gels were captured using a Sharp JX330 flat-bed scanner, and image analysis of the protein profiles was performed using Amersham Pharmacia Biotech ImageMaster 2-D Elite software. The relative amount of each protein spot was calculated and expressed by the software as the percentage of the spot volume and represented the intensity of each individual spot compared to the intensity of the whole gel. The genetic similarity coefficient between two genotypes was estimated according to Dice. The similarity-derived dissimilarity matrix was used in the cluster analysis by using the unweighted pair-group method with arithmetic averages (UPGMA).

\section{Statistical analysis:}

Data were subjected to statistical analysis according to Snedecor and Cochram (1982) by one way ANOVA employing a completely randomized design. eukocytic layer present in the interface was separated to obtain lymphocytes.

\section{RESULTS}

S. aureus strain was exposed to different heat treatments for 24 and $48 \mathrm{hrs}$, the first treatment at $25^{\circ} \mathrm{C}$ showed non significant effect on lymphocytes transformation in response to phytoheamagglutinin as in table (1). When $S$. aureus was incubated with the lymphocytes at $37{ }^{\circ} \mathrm{C}$ for $24 \mathrm{hrs}$, there was no significant stimulation in response to phytoheamagglutinin, but there was significant stimulation after its incubation for $48 \mathrm{hrs}$ when compared with the control. Table (1).

Lymphocytes transformation showed high significant stimulation in response to phytoheamagglutinin when incubated with $50^{\circ} \mathrm{C}$ heat treated $S$. aureus for 24 and 48 hrs. Table (1).

By comparing the results of lymphocytes incubated with $S$. aureus exposed to different temperatures and times $\left(50{ }^{\circ} \mathrm{c}\right.$ for both 24 and $\left.48 \mathrm{hrs}\right)$, we found that there were significant stimulation of lymphocytes transformation in response to phytoheamagglutinin when it was incubated at $50{ }^{\circ} \mathrm{c}$ for both 24 and $48 \mathrm{hrs}$ in comparison to the other groups. Table $(2,3)$. 
Table1: Lymphocyte transformation activeties in the presence and absence of $S$. aureus at different incubation tempretures and time.

\begin{tabular}{|c|c|c|c|c|c|c|}
\hline \multirow{2}{*}{ incubation times } & \multicolumn{2}{|c|}{$25^{\circ} \mathrm{C}$} & \multicolumn{2}{|c|}{$37^{\circ} \mathrm{C}$} & \multicolumn{2}{|c|}{$50^{\circ} \mathrm{C}$} \\
\hline & Control & $\begin{array}{c}\text { Cells with } \\
\text { bacteria }\end{array}$ & Control & $\begin{array}{c}\text { Cells with } \\
\text { bacteria }\end{array}$ & Control & $\begin{array}{c}\text { Cells with } \\
\text { bacteria }\end{array}$ \\
\hline $24 \mathrm{hrs}$ & $0.741 \pm 0.081$ & $0.494 \pm 0.060$ & $0.679 \pm 0.008$ & $0.834 \pm 0.033$ & $0.628 \pm 0.048$ & $1.808 \pm 0.050^{* * * *}$ \\
\hline $48 \mathrm{hrs}$ & $0.677 \pm 0.058$ & $0.699 \pm 0.130$ & $1.55 \pm 0.139$ & $2.326 \pm 0.129^{* * *}$ & $.0 .638 \pm 0.048$ & $3.196 \pm 0.297^{* * *}$ \\
\hline
\end{tabular}

**** significant at $\mathrm{P}<0.05$

Table 2: Effect of different heat treatments of S. aureus on lymphocyte transoformation activity at $24 \mathrm{hrs}$. incubation temperature.

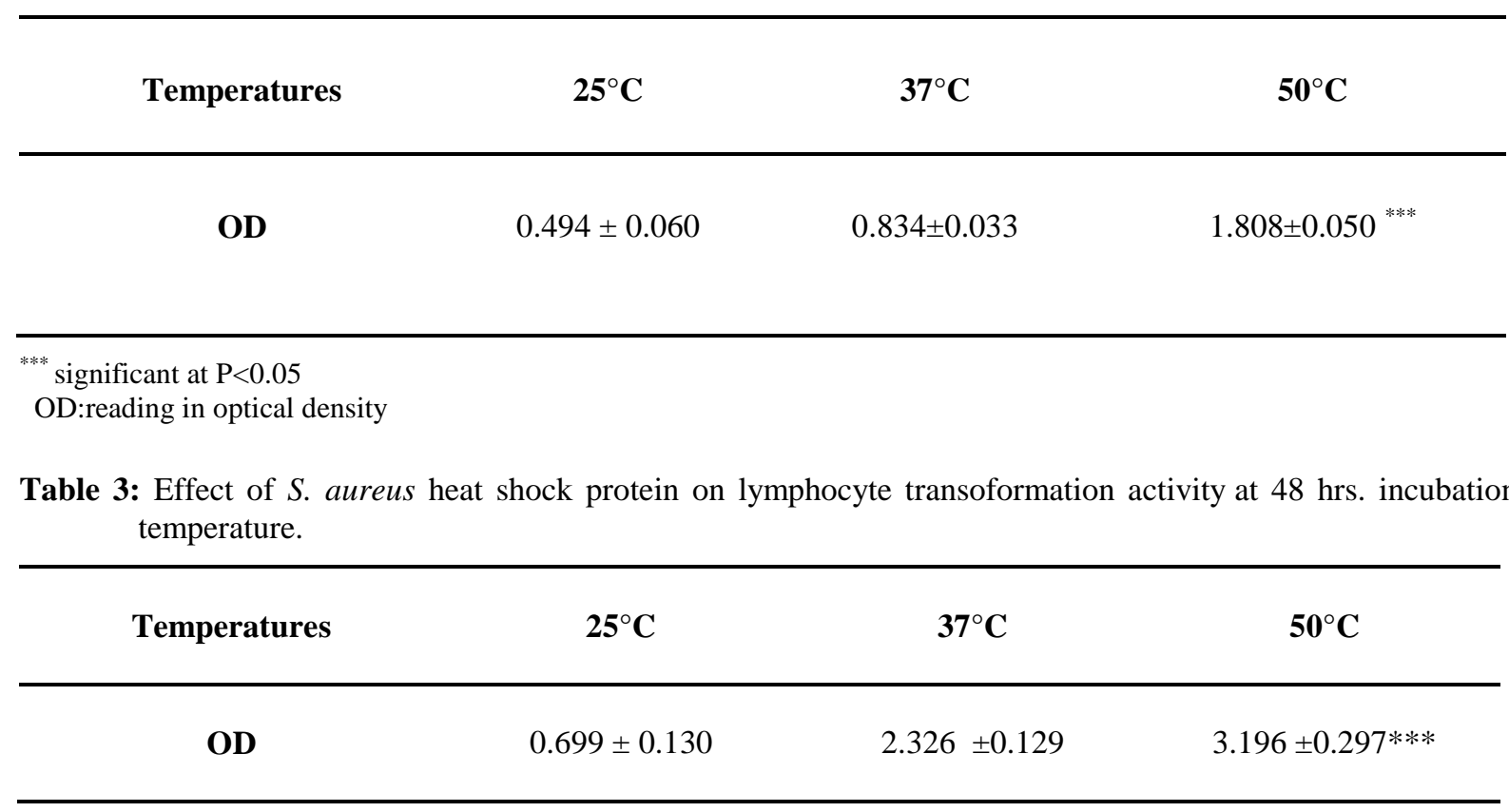

\footnotetext{
****highly significant at $\mathrm{P}<0.05$

OD: reading in optical density
}

Heat shock proteins pattern of $S$. aureus isolates: The one-dimensional SDS-PAGE of HSPs revealed protein profiles containing 16-18 discrete bands with molecular weight of 13-176 kDa. (Fig.1). The highest molecular weight protein band $(176 \mathrm{kDa})$ was present only when the $S$. aureus was incubated at $37^{\circ} \mathrm{C}$ for 48 hrs and the lowest $(13 \mathrm{kDa})$ was when the $S$. aureus was incubated at $25^{\circ} \mathrm{C}$ for $48 \mathrm{hrs}$.

HSPs70 were highly expressed by $22.7 \%$ when the $S$. aureus exposed to $50^{\circ} \mathrm{C}$ for $48 \mathrm{hrs}$, while the lowest percentage $5.3 \%$ was found when $S$. aureus exposed to $25^{\circ} \mathrm{C}$ for $48 \mathrm{hrs}$.

The dendrogramatic analysis of the HSPs (Fig. 2) group expressed after exposure of $S$. aureus cells to $50^{\circ} \mathrm{C}$ for $24 \mathrm{hrs}$ (Lane 1) showed the highest similarity $(84.21 \%)$ with those expressed after exposure of $S$. aureus to $50^{\circ} \mathrm{C}$ for $48 \mathrm{hrs}$ (Lane2).

On the other hand, the group of HSPs produced by the $S$. aureus when exposed to $50^{\circ} \mathrm{C}$ for $24 \mathrm{hrs}$ (Lane 1), $50^{\circ} \mathrm{C}$ for $48 \mathrm{hrs}$ (Lane 2) differed by $75.36 \%$ with the HSPs produced after exposure of $S$. aureus cells to $37^{\circ} \mathrm{C}$ for $24 \mathrm{hrs}, 25^{\circ} \mathrm{C}$ for $24 \mathrm{hrs}$ and $48 \mathrm{hrs}$ (Lanes 3,5 and 6). While the group of HSPs produced by $S$. aureus when exposed to $37{ }^{\circ} \mathrm{C}$ for $48 \mathrm{hrs}$ (Lanes 4) differed by $74.58 \%$ with the HSPs produced from the rest of the groups (Lanes1,2,3,5 and 6). 


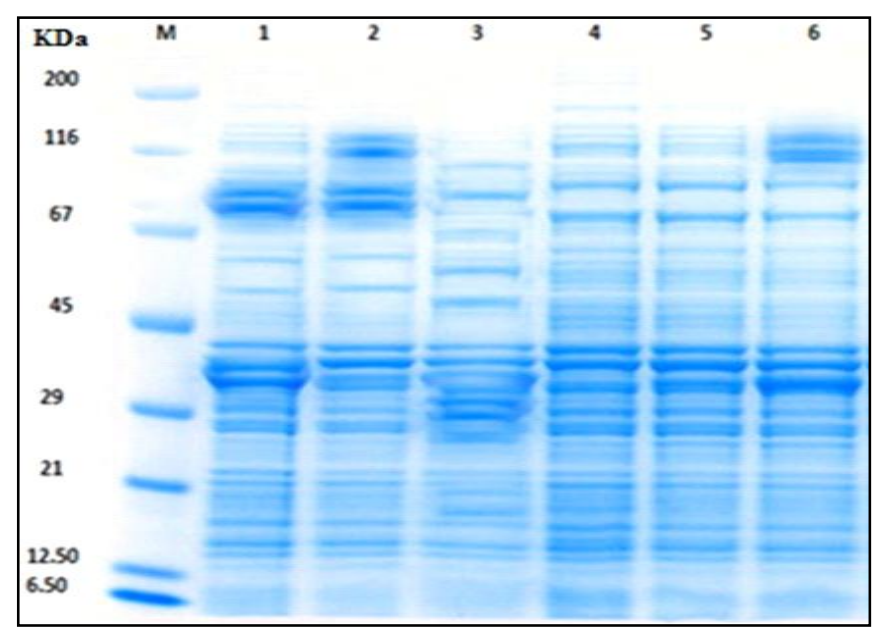

Fig (1): Effect of heat shock treatment on the pattern of protein synthesis in S. aureus isolates. Marker lane (M) (200, 116, 67, 45, 29, 21, 12.50 and 6.50 KDa.).

Lane1. S. aureus incubated at $50^{\circ} \mathrm{c}$ for $24 \mathrm{hrs}$.

Lane2. S. aureus incubated at $50^{\circ} \mathrm{c}$ for $48 \mathrm{hrs}$.

Lane3. S. aureus incubated at $37^{\circ} \mathrm{c}$ for $24 \mathrm{hrs}$.

Lane4. S. aureus incubated at $37^{\circ} \mathrm{c}$ for $48 \mathrm{hrs}$.

Lane5. S. aureus incubated at $25^{\circ} \mathrm{c}$ for $24 \mathrm{hrs}$.

Lane6. S. aureus incubated at $25^{\circ} \mathrm{c}$ for $48 \mathrm{hrs}$.

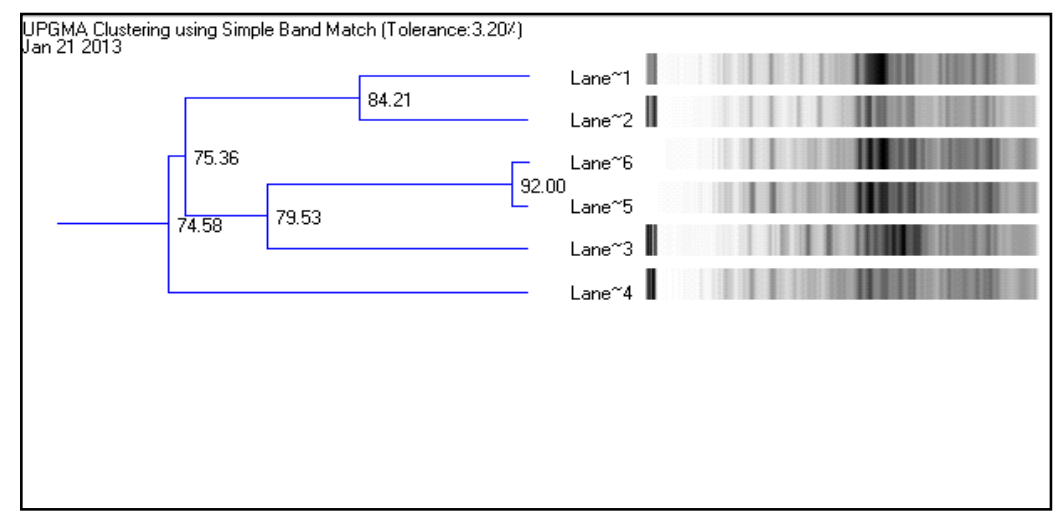

Fig (2): Dendrogram analysis of the expressed HSPs bands of $\boldsymbol{S}$. aureus when subjected to different conditions of temperatures and times.

\section{DISCUSSION}

Staphylococcus aureus is a common and important cause of farm animal diseases including bovine mastitis, tick pyemia (enzootic staphylococcosis), abscesses, dermatitis, furunculosis, meningitis, osteomyelitis, food poisoning, and wound suppuration. Staphylococci (peptidoglycan, lipoprotein, or teichoic acid), triggering innate host immune responses that escape killing replicate in infected tissues and generate proinflammatory responses mediated by the release of cytokines and chemokines from macrophages, neutrophils, and other immune cells Jonsson et al. (2003).

Innate immune responses limit the establishment of infectious foci and thereby reduce the severity of staphylococcal infections. These early events culminate in the activation of adaptive immune responses, during which $\mathrm{T}$ and $\mathrm{B}$ cells capable of specific antigen recognition lead to the eradication of Staphylococci.Wardenburg et al. (2006).

Heat shock proteins (HSP) are intracellular molecular chaperones with many immunological functions. They are high immunogens with further important role in vaccine development against infectious diseases. They have an anti-inflammatory effect on various inflammatory conditions such as infection, ischemia injury, and cardiovascular diseases. They also have recently shown to mediate a range of powerful effects in neuronal cells and immune cells Chen (2007) and Calderwood et al. (2007). HSP act as adjuvant that can augment the immunogenicity of weak antigens and can stimulate antigen presenting cells, lymphocytes and macrophages. Holakuyee et al. (2012) and Noort et al. (2013). 
Lymphocyte proliferation assay (LPA) measures the ability of lymphocytes to undergo clonal proliferation when stimulated by a foreign molecule, antigen or mitogen in vitro so we studied the effect of heat treated S. aureus on lymphocytes function and proliferation.

The incubation of lymphocytes with $S$. aureus at $37^{\circ} \mathrm{C}$ for 2 different incubation periods demonstrated significant stimulation in lymphocytes proliferation at $(\mathrm{p}<0.05)$ (Table 1,2). At the same time there was high significant stimulation when $S$. aureus strain was incubated at $50^{\circ} \mathrm{C}$ for 24 and $48 \mathrm{hrs}$. This finding was supported by MEI-TENG LOH. (1995) who reported that Staphylococcal enterotoxins (SE) bind to major histocompatibility complex (MHC) class II molecules and the $\mathrm{V} \beta$ region of $\mathrm{T}$ cell receptors (TCR) and subsequently induces $\mathrm{T}$ cell proliferation and Taylor et al. (2012) who said that the bacterial superantigen exotoxins of Staphylococcus aureus and Streptococcus pyogenes are potent stimulators of polyclonal T-cell proliferation.

These results may be attributed to the production of different group of heat shock protein which affect the lymphocyte proliferation that run in parallel with the results of Tsan and Baochong (2009) who mentioned that Heat shock proteins (HSPs) such asHSP 60, Hsp70, Hsp90, and gp96, have been reported to play important roles in antigen presentation and crosspresentation, activation of macrophages and lymphocytes.

In this study the heat treated Staphylococcus aureus was investigated using high-resolution SDS-PAGE electrophoresis. We found that the same heat-specific proteins were induced in response to heat shock but that the level of induction varied with the temperature and time and was most pronounced after $48 \mathrm{hrs}$ exposure to $50^{\circ} \mathrm{C}$. The HSP70 family was the most prominantly expressed. They were present in increased amounts or were newly synthesized after heat shock (Fig. 1). They were designated heatspecific stress proteins because they were either newly synthesized or overexpressed in Staphylococcus aureus cells specifically in response to heatshock. These findings look like those of Osman et al. (2009).

Dendrogram analysis revealed that the highest degree of similarity (84.21\%) expressed after exposure of $S$. aureus to $50^{\circ} \mathrm{C}$ for $24 \mathrm{hrs}$ (Lane 1) with those expressed after exposure of $S$. aureus cells to $50{ }^{\circ} \mathrm{C}$ for $48 \mathrm{hrs}$ (Lane 2). Our data is coincided with Mita et al. (1997) who subjected Sunflower suspension cell cultures to different heat treatments and the electrophoretic patterns of heat-induced endocellular and secreted proteins were analyzed, he found that two major polypeptides with specific molecular weights were strongly induced.
We concluded that, heat shock proteins have a stimulatory effect on the most important immune cells (lymphocytes) and the electrophoretic profile showed that the increasing time and degree of heat stress produced more prominent level of these heat stress proteins.

Acknowledgement: The authers thank Prof. dr. Hany Hasan for his support and Dr. Abeer Anwar for her technical assistance.

\section{REFERENCES}

Calderwood, S.K.; Mambula, S.S. and Gray, P.J.J.R. (2007): Extracellular heat shock proteins in cell signaling and immunity. Ann N Y Acad Sci.; 1113: 28-39.

Chen, Y.; Voegeli, T.S.; Liu, P.P.; Noble, E.G. and Currie, R.W. (2007): Heat shock paradox and a new role of heat shock proteins and their receptors as anti-inflammation targets. Inflamm. Allergy Drug Targets.;6 (2): 91-100.

Chin, J.; Turner, B.; Barchia, I. and mullbacher, A. (2000): Immune Response To Orally Consumed Antigens And Probiotic Bacteria. Immunol Cell Biol. 78[1], 55-66.

$\begin{array}{lllll}C & L & S & I & \text { (2005): Performance standards for }\end{array}$ antimicrobial susceptibility testing. C L S I approved standard M100-S15. clin. And Labor. Stand. Instit. Wayne.

Cruikshank, R.; Dugid, J.P.; Morromain, B.P. and Swaim, R.H. (1975): Medical Microbiol.12 ${ }^{\text {th }}$ ed. vol II, chruchil Livingstone. Edinberg, London and NewYork.

De Maio, A. (January 1999): "Heat shock proteins: facts, thoughts, and dreams". Shock (Augusta, Ga.) 11 (1): 1-12. doi: 10.1097/00024382199901000-00001. PMID 9921710

Holakuyee, M.; Mahdavi, M.; Mohammad, Hassan Z. and Abolhassani, M. (2012): Heat Shock Proteins Enriched-Promastigotes of Leishmania major Inducing Th2 Immune Response in BALB/c Mice. Iran Biomed J.; 16(4): 209-17.

Jonsson, L.M.; Mazmanian, S.K.; Schneewind, O.; Bremell, T. and Tarkowski, A. (2003): The role of Staphylococcus aureus Sortase A and Sortase B in murine arthritis. Microb Infect (5): 775-780.

Kloos, W.E.; Lambe, D.W.; Balows, A.; Hausler, W.J.; Herrmann, K.L.; Isenberg, H.D. and Shadomy, H.J. (1991): Manual of clinical microbiology $5^{\text {th }}$ ed. American society for microbiology, Washington DC.

Koneman, E.W.; Allen, S.D.; Dowell, V.R.; Janda, W.M.; Sommess, H.M. and Winn, W.C. (1988): color atlas and text book of diagnostic microbiology. J.B. Lippincott company. Philadelphia, $3^{\text {rd }}$ ed. 
Love, B.C. and Hirsh, D. (1994): Pasteurella multocida produces heat shock proteins in turkeys. Infect Immun., 62: 1128

Maniatis, T.; Fritsch, E.F. and Sambrook, J. (1982): Molecular cloning; a laboratory manual. Cold spring Harbor Laboratory. Cold Sprig Harbor, N N.Y.

Mei-Teng Loh; Nalini Srinivasan; Soh-Ha Chan and EE-Chee Ren (1995): Hybridoma. October 1995, 14(5): 429-433. doi: 10.1089/hyb. 1995.14.429 Inhibition of Staphylococcal Enterotoxin-Driven Lymphocyte Proliferation by Anti-MHC Class II Monoclonal Antibody.

Mita, G.; Nocco, V.; Greco, P. and Rampino, C. Perrotta (1997): Secreated heat shock protein in sunflower cell culture. Plant cell reports (16): 792-796.

Osman, Kamelia, M.; Hassan, Hany; Soliman, Waleed S.; Amin, Zeinab M.S. (2009): Expression and dendrogram analysis of heat shock proteins in culture media of Aeromonas hydrophila. Advances in Natural and Applied Sciences.

Quinn, P.J.; Markey, B.K.; Carter, M.E.; Donelly, W.J. and Leonard, F.C. (2002): Veterinary Microbiology and Microbial Disease.

Senedecor, G.W. and Cochram, W. (1982): Statistical Methods, $8^{\text {th }}$ ed., Lowa state University press. Ames. Lowa, USA.

Srivastava, P. (2002): Roles of heat-shock proteins in innate and adaptive immunity. Nat. Rev. Immunol. 2, 185-194.
Taylor, A.L.; Cross, E.L. and Llewelyn, M.J. (2012): Induction of contact-dependent CD8 (+) regulatory $\mathrm{T}$ cells through stimulation with staphylococcal and streptococcal superantigens. Immunology.; 135(2): 58-67.

Tsan Min-Fu and Baochong Gao (2009): Journal of Leukocyte Biology Volume 85, June 2009, Heat shock proteins and immune system.

Van Noort, J.M.; Bsibsi, M.; Nacken, P.J.; Gerritsen, W.H.; Amor, S.; Holtman, I.R.; Boddeke, E.; Van Ark, I.; Leusink-Muis, T.; Folkerts, G.; Hennink, W.E. and Amidi, M. (2013): Activation of an immune-regulatory macrophage response and inhibition of lung inflammation in a mouse model of COPD using heat-shock protein alpha B-crystallinloaded PLGA microparticles. Biomaterials.; 34(3): 831-40.

Voyich, J.M.; Braughton, K.R.; Sturdevant, D.E.; Whitney, A.R.; Said-Salim, B.; Porcella, S.F.; Long, R.D.; Dorward, D.W.; Gardner, D.J.; Kreiswirth, B.N.; Musser, J.M. and DeLeo, F.R. (2005): Insights into mechanismsused by Staphylococcus aureus to avoid destruction by human neutrophils. J. Immunol. 175: 3907-3919.

Wardenburg B.J.; Williams, W.A. and Missiakas, D. (2006): Host defences against Staphylococcus aureus infection require recognition of bacterial lipoproteins .Proc. Nat. Acad. Sci. U S A. 103(37): 13831-13836.

\section{تحليل بروتينات الصدمة الحرارية فى المنابت البكتيرية للبكتيريا العنقودية الذهبية إيناس جمال ، أشرف نبيه}

في الآونة الآخيرة بدأ العلماء فى در اسة تأثير درجات الحرارة المنخفضة والمرتفعة على افراز بروتينات الصدمة الحر ارية من الخلايا

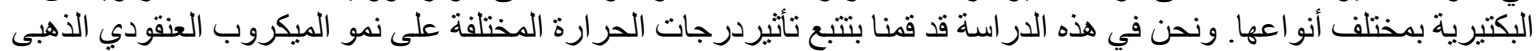

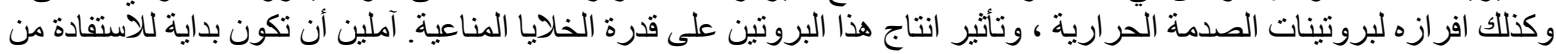

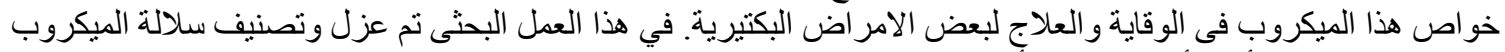

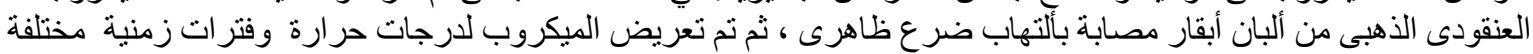

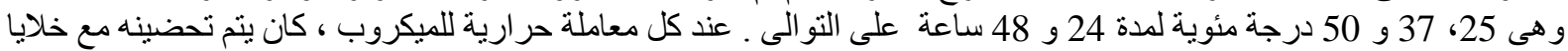

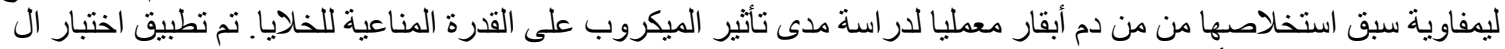

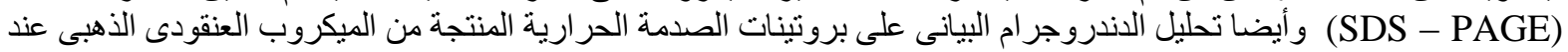

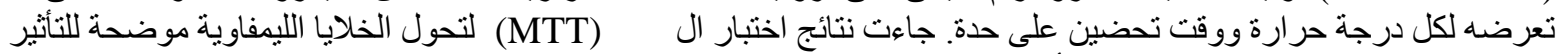

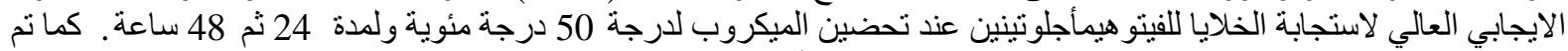

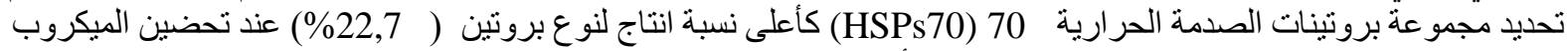

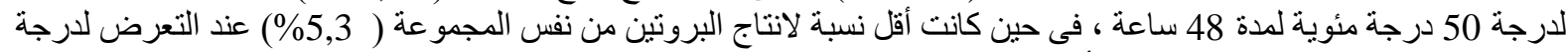

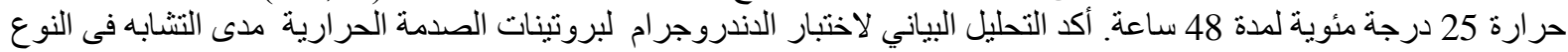

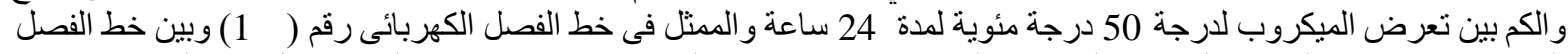

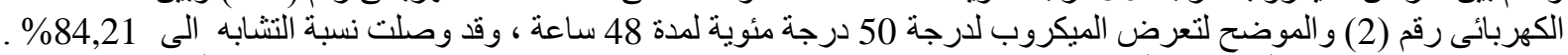

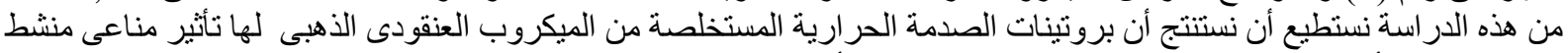

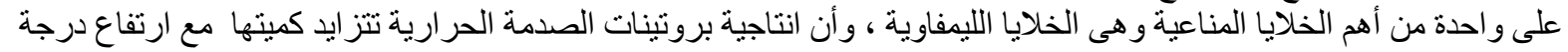

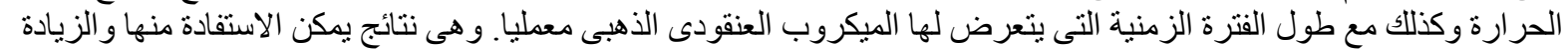

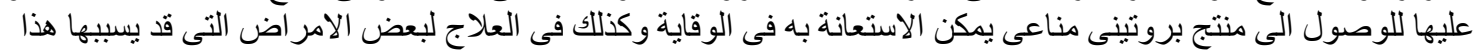

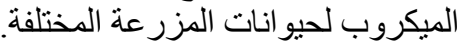

